\title{
Voices from the street: Comics for young men on masculinity, sexuality and HIV-An evidence-based communication initiative
}

Vijaya Nidadavolu

Leena Joshi

Vinita Nathani

Atanu Ghosh

Isidore Phillips

Follow this and additional works at: https://knowledgecommons.popcouncil.org/departments_sbsr-hiv

Part of the Demography, Population, and Ecology Commons, Family, Life Course, and Society Commons, Inequality and Stratification Commons, International Public Health Commons, and the Medicine and Health Commons

How does access to this work benefit you? Let us know!

\section{Recommended Citation}

Nidadavolu, Vijaya, Leena Joshi, Vinita Nathani, Atanu Ghosh, and Isidore Phillips. 2007. "Voices from the street: Comics for young men on masculinity, sexuality and HIV-An evidence-based communication initiative," Research update. New Delhi: Population Council. 
shown that young men believe it is cool to be violent, that condoms must be worn only with sex workers and not with regular partners, that regular girlfriends must be meek and submissive, that a sexually aggressive woman is a 'bad' woman and that it is alright to control women. These notions of mardangi (masculinity) result in young men being abusive with sexual partners, viewing women as objects, engaging in risky sex, not wearing condoms with regular partners, viewing sex as performance and engaging in other risky behaviours, such as injecting drug use. These risky patterns combine to make young men and their sexual partners highly vulnerable to HIV infection. Any communication effort for young men in urban slums must address these notions of masculinity and offer alternatives to the norm so that change is possible in the long run.

\section{Narrative development}

Young men between the ages of 15 and 24 participated in focus group discussions in the four cities in the second phase. These sessions were intended to understand young men's information needs, the retention of messages from ongoing communication initiatives and to collect narratives about everyday situations from their lives that could be used to illustrate the stories. While responding in the sessions, young men shared experiences from either their own lives or from the lives of others that they knew. The narratives clearly revealed that young men did subscribe to norms of masculinity. The responses from the FGDs also demonstrated the need to dispel such notions and suggest alternative norms in a format that young men find attractive. Young men suggested that the comics must be pocket sized, should be very colourful and have an adult look, but should not have covers that are too bold. The young men also revealed that they primarily depend on their peer group for information about health issues and blue films and porn sites on the internet for sex-related information. While they knew about routes of HIV transmission, the risk perception seemed to be low; young men could not relate their own risky behaviours to possible HIV risk. While these trends are indicative of the need for comprehensive and appropriate communication materials for young men, more detailed research is needed to better understand young men's risk perception and myths and misconceptions that are prevalent in this population sub-group.

\section{Pre-testing results}

Based on the narratives collected in the first phase, a series of four comics were designed keeping young men's realities in mind, using the dominant norm of mardangi and proposing an alternative to the norm of a "real man" that is caring, supportive and responsible. The stories were titled: Josh Mein Hosh (Passion with Sense), Khoon Ka Khatra (Just a Drop of Blood), Savdhan Senior (On Your Guard, Senior!) and Pyaar Ka Packet (A Packet of Love). They were drawn in a visual grammar that young men find attractive along with street language that young men use. HIV prevention messages were included at the end of the stories. The draft comic books were then taken back to young men and pre-tested in focus group sessions. Feedback received from young men resulted in many changes to the draft. Young men pointed out that the sequencing of the text was difficult to follow and requested better sequencing so that even those non-conversant with comics would be able to follow the flow of the text. Secondly, men pointed out that the HIVrelated information was too detailed; they requested that the information be woven into the story and be written in language similar to the comics. They requested that the visuals on the covers should be general so the package was not immediately identifiable as an HIV-related information source.

\section{Distribution and replication}

The final product of a series of four comics has been published in four languages: Hindi, Telugu, Bengali and English. Versions were made for Delhi, Mumbai, Kolkata and Hyderabad. Voluntary and Confidential Counselling and Testing Centre (VCCTC) listing specific to each city has been included in the language versions. The local State and District AIDS Control Societies have been approached for integrating elements of their campaigns into this series. In Hyderabad the APSACS-led 'Be Bold' campaign has been integrated into the comics. In Delhi the government call for voluntary counselling and testing has been integrated. Non-governmental organisations across the country have been approached to distribute the comics and, possibly, reprint them. As of March 2007 about 250,000 comics have been distributed in the four cities and it is hoped that this campaign will reach out to a lot more.
(1) Population Council
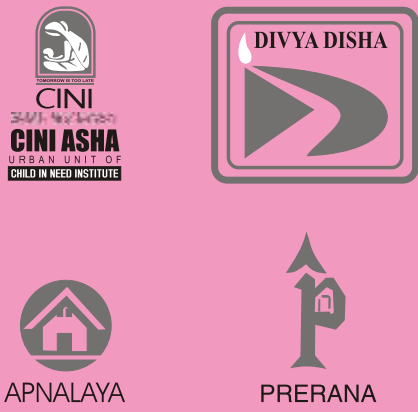

For further information please contact:

Population Council

Zone 5A, Ground Floor

India Habitat Centre, Lodi Road

New Delhi - 110 003, India

Tel: 91-11-2464 2901/02

Fax: 91-11-2464 2903

Email: info-india@popcouncil.org

\section{www.popcouncil.org}

Contributors

Vijaya Nidadavolu (Population Council); Leena Joshi (Apnalaya); Vinita Nathani (Prerana); Atanu Ghosh (CINI Asha); Isidore Phillips (Divya Disha)

Donor

Department for International Development

\section{References}

1. National AIDS Control Organisation. 2006. HIV Situation in India. An Update. New Delhi.

2. A. Singhal and E.M. Rogers. 2003. Combating AIDS: Communication Strategies in Action. Sage Publications, New Delhi.

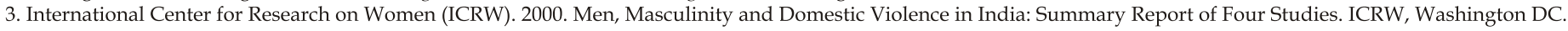

4. R.K. Verma, J. Pulerwitz, V.S. Mahendra et al. 2005. Promoting gender equity among young men: Positive experiences of the Yari-dosti project in India. Sexual Health

Exchange. 2005/2. Royal Tropical Institute, Netherlands.

5. A.G. Dagron. 2001. Making Waves: Stories of Participatory Communication for Social Change. A report of the Rockefeller Foundation, New York. 